\title{
TRANSLATION AND ADAPTATION OF THE PREMATURE INFANT PAIN PROFILE INTO BRAZILIAN PORTUGUESE ${ }^{1}$
}

\author{
Mariana Bueno², Priscila Costa ${ }^{3}$, Angélica Arantes Silva de Oliveira ${ }^{4}$, Roberta Cardoso ${ }^{5}$, Amélia Fumiko \\ Kimura $^{6}$
}

${ }^{1}$ Article extracted from the dissertation - Leite materno ordenhado e glicose $25 \%$ no alívio da dor em recém-nascidos pré-termo tardios submetidos à lancetagem de calcâneo: ensaio clínico randomizado de não inferioridade, presented to the Nursing Graduate Program at School of Nursing, University of São Paulo (EEUSP), 2011.

${ }^{2}$ Ph.D. in Sciences. Adjunct Professor of the Department of Maternal-Child and Public Health Nursing at School of Nursing, Federal University of Minas Gerais (UFMG). Minas Gerais, Brazil. E-mail: buenom@enf.ufmg.br

${ }^{3}$ Master of Sciences. Laboratory Specialist at the Department of Maternal-Child and Psychiatric Nursing, EEUSP. São Paulo, Brazil. Email: priscila2.costa@usp.br

${ }^{4}$ Master of Sciences. Nurse at the Neonatal Intensive Care Unit at the Children's Institute of the Faculty of Medicine, University of São Paulo (USP). São Paulo, Brazil. E-mail: angelicaaso@usp.br

${ }^{5}$ Ph.D. in Fundamental Nursing. Adjunct Professor at Lawrence S. Bloomberg Faculty of Nursing, University of Toronto. Toronto, Canadá. E-mail: rps.cardoso@utoronto.ca

${ }^{6}$ Ph.D. in Nursing. Professor of the Department of Maternal-Child and Psychiatric Nursing at EEUSP. São Paulo, Brazil. E-mail: fumiko@usp.br

\begin{abstract}
The study aimed to translate and to adapt a version of the Premature Infant Pain Profile into the Brazilian Portuguese language. This is a cross-sectional and methodological study for the validation of a translated version of a tool. The process was conducted in four stages: initial translation, synthesis, back-translation, and analysis by experts. Four independent versions of the instrument translated into Brazilian Portuguese were produced. Based on these initial translations, a synthesis version was developed. Two back-translated versions were independently produced, and none showed major differences compared to the original instrument. An expert committee reviewed the summary version and the back-translations with respect to semantic and idiomatic equivalence. The committee considered the translation into Brazilian Portuguese as appropriate. Therefore, the Perfil de Dor no Recém-Nascido Pré-termo was considered adapted to Brazilian Portuguese, for research purposes and for clinical practice. It will contribute to the internationalization of research results in Brazil.
\end{abstract}

DESCRIPTORS: Neonate. Pain. Pain assessment. Nursing.

\section{TRADUÇÃO E ADAPTAÇÃO DO PREMATURE INFANT PAIN PROFILE PARA A LÍNGUA PORTUGUESA}

RESUMO: O estudo objetivou traduzir e adaptar a versão do Premature Infant Pain Profile para a língua portuguesa adotada no Brasil. Trata-se de estudo transversal de caráter metodológico para validação de tradução de instrumento. O processo foi conduzido em quatro etapas: tradução inicial, síntese, retrotradução e análise por juízes. Foram elaboradas quatro versões independentes do instrumento traduzido para o português. Posteriormente, uma versão síntese foi produzida com base nas traduções anteriores. A seguir, duas retrotraduções foram elaboradas independentemente e nenhuma destas apresentou discrepâncias importantes em relação ao instrumento original. Um comitê de juízes analisou a versão síntese e as retrotraduções com relação à equivalência semântica e idiomática e julgou adequada a versão do instrumento em língua portuguesa. Assim, o Perfil de Dor no Recém-Nascido Pré-termo foi considerado adaptado à língua portuguesa do Brasil, para aplicação em pesquisa e na prática clínica, o contribuirá, especialmente, para a internacionalização de pesquisas brasileiras.

DESCRITORES: Recém-nascido. Dor. Avaliação da dor. Enfermagem.

\section{TRADUCIÓN Y ADAPTACIÓN DEL PREMATURE INFANT PAIN PROFILE AL PORTUGUÉS}

\begin{abstract}
RESUMEN: El objetivo del estudio fue traducir y adaptar la versión del Premature Infant Pain Profile para el portugués de Brasil. Es un estudio transversal y metodológico para validación de la tradición de instrumento. El proceso se llevó a cabo en cuatro etapas: traducción inicial, síntesis, retraducción y análisis por jueces. Se establecieron cuatro versiones distintas del instrumento traducido al portugués y una versión sintética fue producida a partir de traducciones anteriores. Posteriormente, dos versiones fueron retraduccidas independientemente y no mostraron diferencias importantes del original. Un comité de jueces revisó la versión resumida y las retraducciónes con respecto a la equivalencia semántica y idiomática y consideraron adecuadas versión del instrumento en portugués. El instrumento Perfil de Dor no Recém-Nascido Pré-termo fue considerado adaptado al idioma portugués, para su aplicación en la investigación y en la práctica clínica. Esto contribuye, especialmente, para la internacionalización de los resultados de la investigación en Brasil.
\end{abstract}

DESCRIPTORES: Recién-nacido. Dolor. Evaluación del dolor. Enfermeria. 


\section{INTRODUCTION}

Pain is a complex and multidimensional phenomenon and its measurement by quantitative and valid methods, is challenging. ${ }^{1}$ Exposure to pain is a damaging factor to newborn's (NB) development in the extra-uterine environment, with short and long term harmful consequences, including events of prolonged and chronic pain and alteration in neurobehavioral responses on future pain episodes, among others. ${ }^{2-4}$

Appropriate pain assessment is essential, since it is the trigger for decision making, mainly concerning the implementation of analgesic measures. Assessing pain requires ability and professional experience, in addition to specific knowledge regarding the most recommended scale for the gestational age and context.

Many instruments for measuring pain in the neonatal period, validated in countries and/ or in their mother tongue, have been published, such as Neonatal Facial Coding System (NFCS), ${ }^{5}$ Douleur Aiguë du Nouveau-né (DAN Scale), ${ }^{6}$ Neonatal Infant Pain Scale (NIPS), ${ }^{7}$ Neonatal Pain, Agitation and Sedation Scale (N-PASS), ${ }^{8}$ Behavioral Indicators of Infant Pain (BIIP), ${ }^{9}$ among others.

Also, the Premature Infant Pain Profile $(\mathrm{PIPP})^{10}$ stands out as a composite multidimensional instrument that evaluates behavioral, physiological and contextual indicators affecting pain in NBs. The PIPP can be used to assess pain in premature and full term infants and is composed by the following indicators: gestational age and behavioral state (contextual factors), heart rate and oxygen saturation (physiologic indicators) and three facial action aspects (behavioral indicators). The scale was initially developed into seven stages: (1) identification of indicators; (2) instrument pilot test; (3) sensibility and specificity assessment of indicators; (4) determination of indicators structure; (5) development of a scoring method for indicators; (6) establishment of internal consistency; and (7) establishment of construct validation. ${ }^{10}$

The validation in the clinical scenario was performed in a randomized study involving 43 NBs, divided according to their gestational age. Each NB was assessed in three distinct events, in a random order: painful event, non-painful event and rest. In addition to the assessment performed by a neonatal pain specialist, a standard nurse was at the NBs' bedside. All NBs were filmed. Images were later analyzed, in real time, second by second. Results indicated the appropriate validation and excellent intra and inter-observers agreement degree for the use of the instrument in a clinical scenario. ${ }^{11}$

In order to validate its employment in measuring post-surgery pain, a study was performed with the objective of comparing the convergent validity of PIPP and Crying, Requires oxygen to keep saturation $>95 \%$, Increased vital signs, Expression, Sleepless Scale (CRIES), ${ }^{12}$ an instrument specifically developed for postsurgery pain assessment. A total of $51 \mathrm{NBs}$ at the gestational age between 28 and 42 weeks were included in this study and results demonstrated both instruments as valid for assessing pain in the first 72 hours after surgery for premature and full term NBs'.13

Therefore, through its initial validation and later studies, the instrument demonstrated robust psychometric properties: moderate internal consistency ( $\alpha=0.59-0.76)$, appropriate intra $(\alpha=0.89-0.91)$ and inter $(\alpha=0.95-0.97)$ observers agreement, in addition to adequate construct validity. ${ }^{10-11,13}$ Moreover, PIPP psychometric adequacy was proved in a study evaluating 62 publications, related to the instrument, from which 14 tested the PIPP psychometric properties. ${ }^{14}$

This scale is frequently employed in studies for the development of new instruments for neonatal pain assessment, as convergent validity is tested. ${ }^{6,8,15}$ Moreover, a total of 48 intervention clinical assays considered PIPP scores as the most important results. ${ }^{14}$

No publications related to the translation and validation of PIPP for Brazilian Portuguese were found in literature. Pain assessment instruments need to be translated and validated before implemented in clinical practice or research in other languages and different countries cultures. The translated version needs to present semantic and idiomatic equivalence, in addition to being culturally and conceptually adjusted in relation to the originally proposed instrument. The PIPP scale has been used in Brazil for clinical setting and research contexts, as demonstrated in some publications,,$^{16-19}$ although no studies related to the translation, adaptation and validation of these instruments in the country were identified within the methodological rigor needed.

Hence, the objective of this study was to translate and adapt the PIPP content and to 
validate the PIPP version for the Brazilian Portuguese language.

\section{METHOD}

This is a cross-sectional study with methodological features for validating the instrument's translation. In order to ensure the quality of the PIPP scale translation and adaptation, the process was developed into four stages. ${ }^{20}$

A) Initial translation: the translation of the PIPP original version into Brazilian Portuguese was performed by four bilingual professionals: three neonatal nurses and one biologist. These translations were independently performed and only the biologist was not informed about the objectives of the study. All four professionals who performed the translation have Portuguese language as their mother tongue.

B) Synthesis: all four translations were compared and translation terms that were not agreed on were discussed by the research authors. Within a consensus, a synthesis version was elaborated from the translated versions.

C) Back-translation: the Brazilian Portuguese synthesis version of the instrument was back-translated into English by two independent translators who had no participation in the initial translation and had not researched the originally published PIPP version. Back-translation was performed by an American English teacher who lives in Brazil, who translates texts in the health area; and by a Brazilian researcher nurse living in Canada, who is a fluent speaker of English. This stage tested the accuracy of the synthesis version. Both back translated versions demonstrated semantic similarity to the terms adopted in the original instrument.

D) Judges analysis: a committee composed of three professionals with Ph.D. degrees in the knowledge area was invited to evaluate the produced versions and therefore to elaborate a consolidated version of the PIPP scale translated into Brazilian Portuguese. Judge selection criteria were: NBs or children's pain clinical and/or research experience, in addition to fluent English. The original PIPP version, the synthesis in Portuguese and the two back-translated versions were sent to these judges. They were guided to evaluate semantic and idiomatic equivalence. Semantic equivalence concerns vocabulary and grammar. Idiomatic equivalence concerns the correct translation of colloquial expressions and idiomatic expressions. Since this is an instrument composed by objective measures, there was no need for evaluating the cultural and conceptual equivalence.

As the evaluation was terminated by the committee, the authors analyzed the suggestions and proposed a final version of the instrument in Brazilian Portuguese.

The instructions for the employment of the instrument, the instrument and the defining features of each one of the facial movements, considered as PIPP indicators, were also translated.

PIPP translation for Brazilian Portuguese was performed after authorization from the scale authors and the Lippincott-Ravens Publishers, the publishing company of The Clinical Journal of Pain, owner of the rights to the original article.

\section{RESULTS}

In the translation and synthesis stages, all four versions of PIPP into Brazilian Portuguese were compared by the research authors. In the initial four versions analysis, each disagreeing word was individually evaluated in order to obtain a consensus and formulation of a synthesis version. The authors consensually decided to keep the word in the Portuguese language that presented more semantics similarity and technical adequacy to the term used in the original version of the instrument (Chart 1).

Chart 1 - Discrepancy presented in the PIPP translation for the Portuguese language and the agreed consensus

\begin{tabular}{|c|c|c|}
\hline Original term & Translation discrepancy & Consensus \\
\hline Infant & $\begin{array}{c}\text { Bebêe } \\
\text { Criança } \\
\text { Recém-nascido }\end{array}$ & recém-nascido \\
\hline Chart & $\begin{array}{c}\text { Quadro } \\
\text { Prontuário }\end{array}$ & prontuário \\
\hline
\end{tabular}




\begin{tabular}{|c|c|c|}
\hline Original term & Translation discrepancy & Consensus \\
\hline Quiet & $\begin{array}{l}\text { Calmo } \\
\text { Quieto }\end{array}$ & quieto \\
\hline Facial movements & $\begin{array}{c}\text { Movimentos faciais presentes } \\
\text { Movimentos faciais }\end{array}$ & movimentos faciais \\
\hline None & $\begin{array}{l}\text { Não } \\
\text { Nenhum } \\
\text { Nada }\end{array}$ & nenhum \\
\hline Minimum & $\begin{array}{l}\text { Mínimo } \\
\text { Pouco }\end{array}$ & mínimo \\
\hline Maximum & $\begin{array}{l}\text { Máximo } \\
\text { Muito }\end{array}$ & máximo \\
\hline Score & $\begin{array}{c}\text { Escore } \\
\text { Pontuação }\end{array}$ & pontuação \\
\hline Brow bulge & $\begin{array}{c}\text { Fronte franzida } \\
\text { Sobrancelha saliente } \\
\text { Sobrancelha arqueada }\end{array}$ & sobrancelha saliente \\
\hline Eye squeeze & $\begin{array}{l}\text { Olhos espremidos } \\
\text { Olhos apertados } \\
\text { Olhos comprimidos }\end{array}$ & olhos espremidos \\
\hline
\end{tabular}

No difficulties were found in the translation of the instrument in general, since the scale is composed of technical terms and evaluates objective measure parameters, not including psychosocial phenomena. Regarding the back-translation, there were no important discrepancies between both back-translated versions and the original PIPP ver- sion. Moreover, no difficulties were demonstrated by translators for the back-translation.

In the evaluation by the judges committee, the semantic and idiomatic equivalence analysis was individually performed by three health area professionals. For analysis presentation, judges were randomly defined as $\mathrm{A}, \mathrm{B}$ and $\mathrm{C}$ (Chart 2).

Chart 2 - Committee evaluation and alterations suggested by judges for the PIPP scale translation

\begin{tabular}{|l|c|c|c|}
\hline & Semantics equivalence & Idiomatic equivalence & Suggested alteration \\
\hline Judge A & Equivalent & $\begin{array}{c}\text { Predominantly equivalent, with the suggestion of } \\
\text { altering the translation for the word "sleep" }\end{array}$ & $\begin{array}{c}\text { Substitution of the term } \\
\text { "sono" by "dormindo" }\end{array}$ \\
\hline Judge B & Equivalent & Equivalent & None \\
\hline Judge C & Equivalent & Equivalent & None \\
\hline
\end{tabular}

At the end of the process, the Portuguese language version of the instrument was considered equivalent, regarding semantic and idiomatic aspects, to the PIPP original version published in English. Therefore, the produced version, named Perfil de Dor no Recém-Nascido Pré-termo (Chart 3), is appropriately adapted to Brazilian Portuguese.

Método de pontuação:

1. Familiarize-se com cada indicador e com a forma como devem ser pontuados.

2. Pontue a idade gestacional (de acordo com o prontuário) antes de começar.

3. Pontue o estado comportamental observando o recém-nascido por 15 segundos imediatamente antes do procedimento.

4. Registre a frequência cardíaca e a saturação de oxigênio basais.

5. Observe o recém-nascido por 30 segundos imediatamente após o procedimento. Você terá que olhar alternadamente o monitor e o rosto do recém-nascido. Pontue as alterações nos indicadores fisiológicos e na expressão facial observadas durante esse intervalo e registre os dados imediatamente após o período de observação.

6. Calcule a pontuação final. 
Chart 3 - Premature Infant Pain Profile - Brazilian version (Perfil de Dor no Recém-nascido Pré-termo)

\begin{tabular}{|c|c|c|c|c|c|c|}
\hline Processo & Indicador & 0 & 1 & 2 & 3 & Pontuação \\
\hline \multirow{2}{*}{$\begin{array}{l}\text { Prontuário } \\
\text { Observe o } \\
\text { recém-nascido } \\
\text { por } 15 \mathrm{~s} \\
\text { Observe } \\
\text { FC: } \\
\text { Sat } \mathrm{O}_{2}:\end{array}$} & $\begin{array}{l}\text { Idade } \\
\text { gestacional }\end{array}$ & $\begin{array}{l}36 \text { semanas ou } \\
\text { mais }\end{array}$ & $\begin{array}{l}32-35 \text { semanas, } \\
6 \text { dias }\end{array}$ & $\begin{array}{l}28-31 \text { semanas, } \\
6 \text { dias }\end{array}$ & $\begin{array}{l}\text { Menos de } 28 \\
\text { semanas }\end{array}$ & \\
\hline & $\begin{array}{l}\text { Estado com- } \\
\text { portamental }\end{array}$ & $\begin{array}{l}\text { Ativo/acordado } \\
\text { Olhos abertos } \\
\text { Movimentos } \\
\text { faciais }\end{array}$ & $\begin{array}{l}\text { Quieto/ } \\
\text { acordado } \\
\text { Olhos abertos } \\
\text { Movimentos } \\
\text { faciais ausentes }\end{array}$ & $\begin{array}{l}\text { Ativo/sono } \\
\text { Olhos fechados } \\
\text { Movimentos } \\
\text { faciais }\end{array}$ & $\begin{array}{l}\text { Quieto/sono } \\
\text { Olhos fechados } \\
\text { Movimentos } \\
\text { faciais ausentes }\end{array}$ & \\
\hline \multirow{5}{*}{$\begin{array}{l}\text { Observe o } \\
\text { recém-nascido } \\
\text { por } 30 \mathrm{~s}\end{array}$} & FC máx & $\begin{array}{l}\text { Aumento de } \\
\text { 0-4 bpm }\end{array}$ & $\begin{array}{l}\text { Aumento de } \\
5-14 \text { bpm }\end{array}$ & $\begin{array}{l}\text { Aumento de } \\
15-24 \text { bpm }\end{array}$ & $\begin{array}{l}\text { Aumento de } 25 \\
\text { bpm ou mais }\end{array}$ & \\
\hline & Sat $\mathrm{O}_{2}$ mín & $\begin{array}{l}\text { Queda de } \\
0-2.4 \%\end{array}$ & $\begin{array}{l}\text { Queda de } \\
2.5-4.9 \%\end{array}$ & $\begin{array}{l}\text { Queda de } \\
5-7.4 \%\end{array}$ & $\begin{array}{l}\text { Queda de } 7.5 \% \\
\text { ou mais }\end{array}$ & \\
\hline & $\begin{array}{l}\text { Sobrancelhas } \\
\text { salientes }\end{array}$ & $\begin{array}{l}\text { Nenhum } \\
0-9 \% \text { do tempo }\end{array}$ & $\begin{array}{l}\text { Mínimo } \\
10-39 \% \text { do } \\
\text { tempo }\end{array}$ & $\begin{array}{l}\text { Moderado } \\
40-69 \% \text { do } \\
\text { tempo }\end{array}$ & $\begin{array}{l}\text { Máximo } \\
70 \% \text { do tempo } \\
\text { ou mais }\end{array}$ & \\
\hline & $\begin{array}{l}\text { Olhos } \\
\text { espremidos }\end{array}$ & $\begin{array}{l}\text { Nenhum } \\
0-9 \% \text { do tempo }\end{array}$ & $\begin{array}{l}\text { Mínimo } \\
10-39 \% \text { do } \\
\text { tempo }\end{array}$ & $\begin{array}{l}\text { Moderado } \\
40-69 \% \text { do } \\
\text { tempo }\end{array}$ & $\begin{array}{l}\text { Máximo } \\
70 \% \text { do tempo } \\
\text { ou mais }\end{array}$ & \\
\hline & $\begin{array}{l}\text { Sulco } \\
\text { nasolabial }\end{array}$ & $\begin{array}{l}\text { Nenhum } \\
\text { 0-9\% do tempo }\end{array}$ & $\begin{array}{l}\text { Mínimo } \\
10-39 \% \text { do } \\
\text { tempo }\end{array}$ & $\begin{array}{l}\text { Moderado } \\
40-69 \% \text { do } \\
\text { tempo }\end{array}$ & $\begin{array}{l}\text { Máximo } \\
70 \% \text { do tempo } \\
\text { ou mais }\end{array}$ & \\
\hline
\end{tabular}

Pontuação total:

Descrições da mímica facial: sobrancelhas salientes (abaulamento, formação de dobras e fendas verticais acima e entre as sobrancelhas, como resultado da aproximação das sobrancelhas), olhos espremidos (identificado pelo apertar dos olhos ou abaulamento das pálpebras, abaulamento das pregas palpebrais), sulco nasolabial (primariamente manifestada elevação e aprofundamento do sulco nasolabial - linha ou ruga que se inicia junto às asas da narina e se estende para baixo e para a parte externa dos lábios.

\section{DISCUSSION}

For the present study, the PIPP was selected due to its use in a broad number of intervention researches, as the main outcome, and also in validation studies for new neonatal pain assessment instruments, as previously mentioned. The robust psychometric properties also affected the selection of the PIPP as the neonatal pain assessment instrument to be translated into Brazilian Portuguese. Translation for this instrument into Icelandic ${ }^{21}$ and Norewgian, ${ }^{22}$ following similar methodological procedures to those adopted in the present study were previously published.

Although it is an objective measures scale, the PIPP translation and adaptation were considered essential for Brazilian Portuguese. This procedure aimed to ensure the equivalence between the original and the translated versions and therefore to contribute to the maintenance of the instrument psychometric properties..$^{20}$ The instrument translation and adaptation process, developed into other languages, enables saving time and financial resources, in addition allows the comparison of research results developed in different countries. ${ }^{23-24}$

PIPP is a composite multidimensional instrument for pain assessment in preterm and full term NBs. Seven indicators are assessed, with a score ranging from zero to three for each indicator. The total score ranges from zero to 18 points in full term NBs, and from zero to 21 points in preterms. Scores equal to or lower than 6 points indicate absence or minimum pain, scores above 12 indicate moderate to intense pain. 
NBs' inability to verbally communicate require indirect terms for the assessment of neonatal pain that, in general, consider isolated or combined behavioral, physiological and contextual indicators. Therefore, the appropriate acute pain assessment in neonates comprises careful observation of the intensity and quality of pain indicators, by reliable and valid measures. ${ }^{14}$ It requires, from the evaluator, deep related knowledge of neonatal pain anatomy and physiology, from neonatal pain indicators, and, especially, from the pain assessment instruments. Many instruments, with different psychometric properties, applicability and clinical utility are available in literature. ${ }^{14}$ However, currently there is no ideal instrument for pain assessment in the neonatal population. ${ }^{25}$ The excessive number of published scales reflects the difficulty in appropriately and accurately assess neonatal pain.

The choice for an instrument used by another culture and language brought the researcher to adjusting it to this reality, by transcultural translation and adaptation processes. Obtaining the equivalence between instruments is one of the steps to ensure the appropriateness of the translation. The translation and adaptation process ensure content validity of an instrument into another language and culture, making it reliable. Considering an instrument as reliable is to believe in its measuring capacity, minimizing or eliminating error events. ${ }^{20}$

Therefore, the use of the Perfil de Dor do Recémnascido Pré-termo, in clinical practice and in the research and teaching scenarios, will reflect in the use of an appropriate and adapted instrument to Brazilian Portuguese. It is important to stress that a different strategy must be used to employ the PIPP at the bedside. When observation is performed in real time, facial action is measured according to its duration magnitude (none, minimum, moderate or maximum). For research purposes, when the NB can be filmed for posterior detailed analysis of his or her facial action and the attribution of scores, the scoring method consists on the percentage of time of occurrence of the events for each facial action. Also, training the evaluator regarding the instrument employment is essential in both scenarios described above. Educational initiatives such as those reports previously published, ${ }^{26-27}$ are useful strategies for dedicated professionals to health care and research in the neonatal area.

The use of an appropriately translated and validated instrument will contribute to the internationalization of Brazilian research results. How- ever, verifying the clinical applicability and usefulness is a necessary measure that will contribute in the neonatal pain control and assessment process.

Measuring psychometric properties of the instrument is also needed in order to strengthen the validation of PIPP into Brazilian Portuguese, although there is a trend in maintaining psychometric properties in translated versions of objective measures instruments.

\section{CONCLUSIONS}

The process of translation and adaptation of the PIPP resulted in an appropriately adapted instrument for Brazilian Portuguese.

The synthesis, the back-translation and the final versions of the translated instrument for the Portuguese language were considered equivalent in semantic and idiomatic aspects in relation to the original version in English. In order to accomplish the instrument validation process, assessment by neonatal care professionals is needed, in addition to the evaluation of the translated instrument's psychometric properties in the Portuguese language.

Searching for neonatal pain assessment strategies must be a target for health professionals, and also implementing pharmacological or nonpharmacological strategies for its relief. Therefore, choosing an appropriate pain assessment instrument is the first step in dealing efficiently with pain in the neonatal population, with the goal to guide pain control and prevention strategies.

\section{ACKNOWLEDGEMENTS}

The authors thank the São Paulo Research Foundation (FAPESP), processes \#2008/52891-8 and \#2008/11607-5.

\section{REFERENCES}

1. Fitzgerald M, Walker SM. Infant pain management: a developmental neurobiological approach. Nat Clin Pract Neurol. 2009 Jan; 5(1):35-50.

2. Buskila D, Neumann L, Zmora E, Feldman M, Bolotin A, Press J. Pain sensitivity in prematurely born adolescents. Arch Pediatr Adolesc Med. 2003 Nov; 157(11):1079-82.

3. Abdulkader HM, Freer Y, Garry EM, FleetwoodWalker SM, McIntosh N. Prematurity and neonatal noxious events exert lasting effects on infant pain behaviour. Early Hum Dev. 2008 Jun; 84(6):351-5.

4. Taddio A, Shah V, Atenafu V, Katz J. Influence of repeated painful procedures and sucrose analgesia 
on the development of hyperalgesia in newborn infants. Pain. 2009 Jul; 144(1-2):43-8.

5. Grunau RV, Craig KD. Pain expression in neonates: facial action and cry. Pain. 1987 Mar; 28(3):395-410.

6. Carbajal R, Paupe A, Hoenn E, Lenclen R, OlivierMartin M. APN: a behavioral acute pain rating scale for neonates. Arch Pediatr. 1997 Jul; 4(7):623-8.

7. Lawrence J, Alcock D, McGrath P, Kay J, McMurray SB, Dulberg C. The development of a tool to assess neonatal pain. Neonatal Netw. 1993 Sep; 12(6):59-66

8. Hummel P, Puchalski M, Creech SD, Weiss MG. Clinical reliability and validity of the N-PASS: neonatal pain, agitation and sedation scale with prolonged pain. J Perinatol. 2008 Jan; 28(1):55-60.

9. Holsti L, Grunau RE. Initial validation of the Behavioral Indicators of Infant Pain (BIIP). Pain. 2007 Dec; 132(3):264-72.

10. Stevens B, Johnston C, Petryshen P, Taddio A. Premature infant pain profile: development and initial validation. Clin J Pain. 1996 Mar; 12(1):13-22.

11. Ballantyne M, Stevens B, McAllister M, Dionne K, Jack A. Validation of the premature infant pain profile in the clinical setting. Clin J Pain. 1999 Dec; 15(4):297-303.

12. Krechel SW, Bildner J. CRIES: a new neonatal postoperative pain measurement score. Initial testing of validity and reliability. Paediatr Anaesth. 1995; 5(1):53-61.

13. McNair C, Ballantyne M, Dionne K, Stephens D, Stevens B. Postoperative pain assessment in the neonatal intensive care unit. Arch Dis Child Fetal Neonatal Ed. 2004 Nov; 89(6):F537-41.

14. Stevens B, Johnston C, Taddio A, Gibbins S, Yamada J. The Premature Infant Pain Profile: evaluation of 13 years after development. Clin J Pain. 2010 NovDec; 26(9):813-30.

15. Bellieni CV, Cordelli DM, Caliani C, Palazzi C, Franci N, Perrone S, et al. Inter-observer reliability of two pain scales for newborns. Early Hum Dev. 2007 Aug; 83(8):549-52.

16. Freire NB, Garcia JBS, Lamy ZC. Evaluation of analgesic effect of skin-to-skin contact compared to oral glucose in preterm neonates. Pain. 2008 Sep; 139(1): 28-33.

17. Silva TM, Chaves EMC, Cardoso MVLML. Pain in the newborn during the arterial puncture. Esc Ana
Nery Rev Enferm. 2009 Dec; 13(4):726-32.

18. Chermont AG, Falcão LFM, Silva EHLS, Balda RCX, Guinsburg R. Skin-to-skin contact and/or dextrose for procedural pain relief for term newborn infants. Pediatrics. 2009 Dec; 124: e1101-7.

19. Costa P, Camargo PP, Bueno M, Kimura AF. Dimensionamento da dor durante a instalação do cateter central de inserção periférica em neonatos. Acta Paul Enferm. 2010 Jan-Fev; 23(1):35-40.

20. Beaton D, Bombardier C, Guillemin F, Ferraz MB. Guidelines for the process of cross-cultural adaptation of self-report measures. Spine (Phila Pa 1976). 2000; 25: 3186-91.

21. Jonsdottir RB, Kristjansdottir G. The sensitivity of the premature infant pain profile - PIPP to measure pain in hospitalized neonates. J Eval Clin Pract. 2005 Dec; 11(6):598-605.

22. Vederhus BJ, Eide GE, Natvig GK. Psychometric testing of a Norwegian version of the Premature Infant Pain Profile: an acute assessment tool. A clinical validation study. Int J Nurs Pract. 2006 Dec; 12(6):334-44.

23. Guillemin F, Bombardier C, Beaton D. Cross-cultural adaptation of health-related quality of life measures: literature review and proposed guideline. J Clin Epidemiol. 1993 Dec; 46(12):1417-32

24. Juniper EF, Guyat GH, Jaeschke R. How to development and validate a new quality of life instrument. In: Spilker B, editor. Quality of life assessment in clinical trials. New York: Raven Press Ltd, 1995.

25. Duhn LJ, Medves JM. A systematic integrative review of infant pain assessment tools. Adv Neonatal Care. 2004 Jun;4(3):126-40.

26. Gibbins S, Maddalena P, Yamada J, Stevens B. Testing the satisfaction and feasibility of a computerbased teaching module in the neonatal intensive care unit. Adv Neonatal Care. 2007 Feb; 7(1):43-9.

27. Bueno M, Kimura AF, Leite AM, Costa P, Oliveira AAS, Castral TC, et al. Development of a web-based training program on neonatal pain: Neonatal Pain Assessment Program (Programa de Avaliação da Dor Neonatal - PAD-Neo). In: Proceedings do $13^{\text {th }}$ World Congress on Pain, 2010 Ago 29-Set 02; Montréal, Canadá. Montréal: International Association for the Study of Pain; 2010.

E-mail: buenom@enf.ufmg.br 